\title{
Relationship between Money Supply and Financial Bailout of Small-Scale Agribusiness Firms in Nigeria
}

\author{
Achoja Felix Odemero a \\ a Delta State University, Nigeria , achojafelix@gmail.com, https://orcid.org/0000-0002-9705-4923
}

\section{ARTICLE INFO}

Research Article

2020, Vol. 2(3), 459-470

e-ISSN 2667-5927

Article History:

Received: 22.03.2020

Revised: 07.04.2020

Accepted: 25.05.2020

Available Online: 15.07 .2020

JEL Code: Q14

Keywords: macroeconomics variables, financial bailout, small scale agribusiness, public capital injection.
Relationship between Money Supply and Financial Bailout of Small-Scale Agribusiness Firms in Nigeria

\section{Abstract}

Nigeria had experienced economic recessions in 2008 and 2015 with the consequential financial bailout of the small-scale agribusinesses. It is important to investigate the factors that influence money supply as a source of bailout funds for agribusinesses during the economic recession. The study was carried out to determine the macro-economic correlates of public capital supply for agribusiness financial bailout and its implications for agricultural development in Nigeria. Secondary data were obtained from time-series data that covered from 1992-2018. The choice of data period was due to the fact that the two economic recessions fell within the period under review. Simple regression, correlation matrix, and descriptive statistics were used to analyze the collected data. The descriptive statistics indicate that the mean capital injection into the small-scale agribusiness firms amounted to $\$ 39.3$ million. The simple regression shows that money supply has a positive and significant relationship with the financial bailout of agribusiness firms. Further result shows that money supply has a close relationship with reserve requirement, interest rate, discount rate, and exchange rate. The study concludes that the mean capital injection into the agribusiness sector was low. Money supply for bailout capital injection has a positive and significant relationship with the financial bailout of agribusiness firms and the relevant macroeconomic variables significantly have a close relationship with money supply. The study, therefore, recommends that Policymakers should fine-tune reserve requirement, interest rate, discount rate, and exchange rate during the economic recession to boost the amount of money supply for injection to ailing agribusiness firms during the economic recession. This will further lead to the overall development of agricultural value chain in the Nigerian economy. 


\section{Introduction}

The concept of financial bailout is a poorly explored area in management sciences. The development of the concept of financial bailout was strongly influenced by (Levitin 2011). Financial bailout is important for the development of distressed business entities. This also applies to the cluster concept (Porter, 1998; 2000; 2001; 2003) in which references to all dimensions of financial bailout can be found. Applying the financial bailout to the agribusiness concept is an attempt to understand and explain macroeconomic factors that may affect (positively or negatively) the development of money supply for bailouts in Nigeria.

Financial bailout is recognized as a factor facilitating access to financial capital for the recovery and development of failing business entities. The attainment of maximum financial bailout lacks information and ideas. Therefore, in order to develop new ideas for the attainment of an optimal level of financial bailout should be sought. Bailout is government intervention through Lending, Equity capital, Purchase of asset, Loan guarantee, Regulatory forbearance for firms.

In the case of transaction, the repayment of borrowed funds must be at risk, either because it is not fully collaterized or not fully protected. As a result, one level of government may intervene in the affairs of another level of government. The federal government may bailout a state or local government and a state government may bailout a local government (New York City Seasonal Financing Act, 1975)

Extreme levels of debt and recurring income shock have been reported among small scale enterprises in developing world. This is especially true in rural areas where households are faced with lack of income, lack of basic financial instrument that could mitigate agribusiness failure (Townsend, 2006, Karlan and Morduch 2009)

While benefit of debt relief to individual firms can be substantial, the advantage of unconditional bailouts as an economic tool to improve firms productivity remains highly controversial. Proponents of debt relief argued that extreme levels of indebtedness affect investment and production decision. Hence, debt relief hold the promise of sustaining the productivity of the recipient households or firms (Robert, 2012).

According to Levitin (2011), bailout is an inevitable feature of modern economies in which the interconnectedness of firms means that the economic system has mechanism of bearing risk of an individual firm's distress (Deutsche Bundesbank 2007)). Support measures are either through restructuring mergers or financial injections. Capital injection is an inflow of cash, stock or even debt into a company. When the going concept is threatened, the option is either bankruptcy or a capital injection in form of bailout (Faff, et al. 2010). 
Many economies maintain a deposit insurance scheme as a contingency fund to protect depositors against losses when a financial institution fails to meet its debt obligations. Consequently, selected banks have received fund support from the government when in distress in the form of bailout (Dam and Koetter, 2011; Block 1992).

Agribusiness is an important sector in Nigeria with regards to its contribution to employment, livelihood, and gross domestic product leading to economic development (Jean-Jacques and Alexandra,2011).it is an important employer of labor and a key contributor to wealth and poverty alleviation, as large percentage of the population derive their income from agribusiness and related activities (Ayinde et al. 2009). This broad concept of agricultural financing ensures that funds channeled to agriculture are profitably used for its development, with a concomitant spillover and multiplier effect to the other sectors of the economy (Adofu, et al. 2010).

It is also asserted that the increasing recognition of the need for agricultural financing stems from the desirability to enhance the position of on-farm capitalization in Nigeria agriculture and the fact that the farmers' own savings are normally inadequate to finance the various farming activities. Thus, capital injection into the agricultural sector is imperative in view of the unfavorable terms of trade facing agriculture, declining productivity, low level of adoption of improved technologies and the fact that many investors are in favor of low cost, quick returns, and less risky business ventures compared to agriculture (Oni and Olomola, 1989).

Agribusiness firms' failures have not received a particularly sympathetic hearing from the government. Bailout mechanisms are designed to prevent enterprise failure. The focus of bailout is therefore to save a private enterprise from total collapse or extinction. Important issues such as agribusiness financial bailout were either poorly addressed or totally ignored. There is no agreement on what scale of financial bailout would be most beneficial for small-scale agribusinesses. This paper is interested in the problem of both excessive and insufficient financial bailout of small-scale agribusinesses during an economic downturn.

Funds given to the farmers by the government were diverted because they were not properly supervised. Consequently, the impact of bailout is spread thinly over the sector and expected goals of bailout mechanisms are not met at best. Some factors must correlate with a successful bailout mechanism of agribusiness firms in Nigeria. The identification of the significant macroeconomic variables of financial bailout mechanism could form a good platform for policy choices that would bring development to agribusiness firms in Nigeria. As it stands, there is a dearth of information on the macro-economic correlates of effective financial 
bailout mechanism in Nigeria. It was this information gap that called for this investigation.

This paper addresses the correlates of agribusiness financial bailout using a macro-economic perspective in Nigeria (1992 - 2018).

The specific objectives of the study were to:

(i) Ascertain the mean capital injection that has been released by the government as a financial bailout to agribusiness firms in Nigeria (19922018).

(ii) Examine the relationship between agribusiness financial bailout and money supply.

(iii) Determine the relationship between money supply and macroeconomic variables.

(iv) Identify the weaknesses inherent in the agribusiness financial bailout mechanism in Nigeria.

\section{Literature Review}

The superior role of a financial bailout in achieving external this goal has already been indicated by (Levitin 2011). On the other hand, ungoverned bailout can have a negative impact on the development of firms. This precondition has the benefit of sparing unnecessary expenditure of government resources and prevent the wastage of government resources. Moreover, it is necessitated by the operating definition of bailout itself-that bailout is a form of government assistance or intervention designed to prevent enterprise failure. Government assistance in the absence of reasonable evidence that the firm would fail without relief is not a bailout but a different form of government subsidy.

Capital movements respond to changes in the rate of interest. If the rate of interest on capital is higher than the rate of return on investment, investors find it difficult to repay borrowed funds and thereby suffer credit risk (World Bank, 2008).

The agribusiness sector has suffered some setbacks for several years now. There are cases of short time operational existence and collapse of agribusiness enterprises established due to unforeseen crises. Yet, little or no effort has been made by the government concerning the various crisis that has led to the collapse of the agribusiness firms. Even where efforts are made they are either missdirected or wrong mechanisms of interventions were adopted. Besides, some important mechanisms and characteristics of the bailout are poorly understood or ignored. Other factors that have also led to the poor performance of bailout of firms include inadequate funding and poor management of the bailout process. The bailout mechanism which is supposed to avert the situation or rescue the farmers by providing financial assistance in order to ensure greater stability and 
continuity has not been sufficiently extended to all the aspects of agribusiness value chain.

Naohisa, et al. (2013), investigated capital injection in response to an adverse shock to the economy using the financial accelerator model. They found out that a spread adjusted rule is capable of mitigating the impact of adverse shock it was evident that a positive injection could boost the economy regardless of the type of shock. In all, it was concluded that capital injection has a greater impact on the economy compared to the business owner.

Vern and Gary (2009), they noted that for the purpose of analysis they define bailout financial institutions as an institution that possesses the following elements:

(1) Government intervention during the period of business disruption through lending, equity injection, purchase of assets, loan guarantee, etc by regulating the financial institution

(2) The action taken is pre-emptive and the agribusiness firms benefiting from the intervention do not go out of business or go into bankruptcy.

(3) In the absence of the bailout mechanism, agribusiness firms will be forced to go through receivership in a legal form or become disrupted in its business

A bailout of agribusiness firms involves government interventions through transactions that are targeted to either an agribusiness firm or group of firms. Yet bailout over the years does not reflect a transparent and viable policy justification. As a result, when the Bailout mechanism is implemented, they yield a negative result that is they their miss its intended purpose.

According to Block (1992), most cases of enterprise failure considered or bailout relief by government decision-makers involve uninsurable losses. Private deposit insurance simply was not considered viable. Most federal insurance programs involve risks that met some of the "insurable risk" elements. Therefore, most bailouts in the form of government insurance have been directed to satisfy a greater number of the "insurable risk" elements. For example, by focusing on insurance programs upon a particular group or industry, the government programs come closer to satisfying the requirement that there be a large group of homogeneous exposure units. In contrast to prospective bailouts through federal insurance funds, retrospective bailout legislation is a form of federal backup insurance that meets few, if any, of the "insurable risk" elements. The firm failure may not be accidental but instead, result from poor management decisions made along the way or failed efforts at government regulation. 
When a firm's or industry's failure can be attributed to its own errors in judgment, a question then arises if a bailout program is appropriate for such a situation.

Some progress has been made in addressing the stated problem in the banking sector of the economy. For example, the Central Bank of Nigeria (CBN) injected N620 billion into the troubled banks in 2009 as a form of bailout due to non performing and unsecured loans of the banks, which led to tight credit in the economy (Sanusi 2010). The stock market also collapses by $70 \%$ in $2008-2009$, and many Nigerian banks had to be rescued in order to stabilize the system and return confidence to the market and investors (Sanusi, 2010).

\section{Materials and Methods}

The study area is Nigeria. The capital of Nigeria is Abuja which is located at the centre of Nigeria Africa. Nigeria's estimated 69.9 million hectares of agricultural land about 39.2 million are under permanent pasture with another 2.8 million under permanent crops, leaving about 27.9 million ha for arable crops. Within the last category, it is estimated that some 25 million hectares are cultivated each year implying a high cropping intensity with respect to arable land. Forestry constitutes about 26 million hectares currently. Crops contributes some $27 \%$ of GDP, livestock another 3.3\% and forestry and fisheries 1.5\%. A list of the country's agricultural exports includes cocoa, cotton, vegetables and fruits, leather and these exports represent less than $5 \%$ of export earnings ( $A D B, 2005$ ).

Secondary data were used for the study. Secondary data were obtained from time-series data that covered from 1992-2018. The choice of data period was due to the fact that the two economic recessions and financial bailouts fell within the period under review. The data were collected on the following macroeconomic variables they include agribusiness financing, money supply, liquidity ratio, reserve requirement, discount rate, cash reserve ratio, bank interest rates, inflation rates, exchange rates, and bank lending rates.

The financial bailout initiative by the government is a function of the money supply. Therefore, this relationship is fitted in the simple regression model. Descriptive statistics were used to determine the mean capital injection and the relationship between money supply and macroeconomic variables was fitted in the correlation matrix.

The simple regression model is implicitly stated as:

$A B F=f(M S)$

Where:

$\mathrm{ABF}=$ Agribusiness financing

$F=$ function of (meaning depends on)

$\mathrm{MS}=$ money supply 
The model is explicitly fitted as:

$A B F=(\beta 0+\beta 1 M S)+$

Where:

$\mu=$ stochastic error term

The descriptive statistics is stated as :

Cv $=s t d / m^{*} 100$.

$\mathrm{Cv}=$ coefficient of determination $\mathrm{m}=$ mean $\quad \mathrm{std}=$ standard deviation

The Statistical Package of Social Sciences (SPSS), Version 21 was used to analyze the data. Three functional forms were estimated namely, linear, semi log and double log functions. Correlation matrix was used to run a test of relationship between money supply and some macroeconomic variables.

\section{Results and Discussion}

The result in table 1 shows that the mean capital injection for the agricultural financial bailout is $31.43 \mathrm{M}$ (Thirty-four million, four hundred and thirty thousand nairas). The mean capital injection came from the central bank, IMF, IFAD, and other donor agencies. The 31.43 million as shown in this study is relatively low to create an effective financial bailout in the agribusiness sector in Nigeria.

Table 1: The Mean Capital Injection for Agribusiness Financial Bailout in Nigeria (1992-2018)

\begin{tabular}{ll}
\hline \hline Summary statistics & Values (\#) \\
\hline \hline Maximum & $\# 46.72 \mathrm{M}$ \\
Mean & $\# 31.43 \mathrm{M}$ \\
Minimum & $\# 16.14 \mathrm{M}$ \\
Std. deviation & $\# 214.31$ \\
\hline \hline
\end{tabular}

In Table 2, The coefficient of variation in the amount $t$ released is $55 \%$. The coefficient of variation shows the degree of yearly variation in the amount of money injected for a financial bailout. This finding implies a relatively high rate of unsteady flow of capital for a financial bailout in the agribusiness sector. The unsteady flow of financial resources could be adduced or attributed to shocks in macroeconomic variables in the economy. 
Table 2: Relationship between Money Supply and Agribusiness Financial Bailout

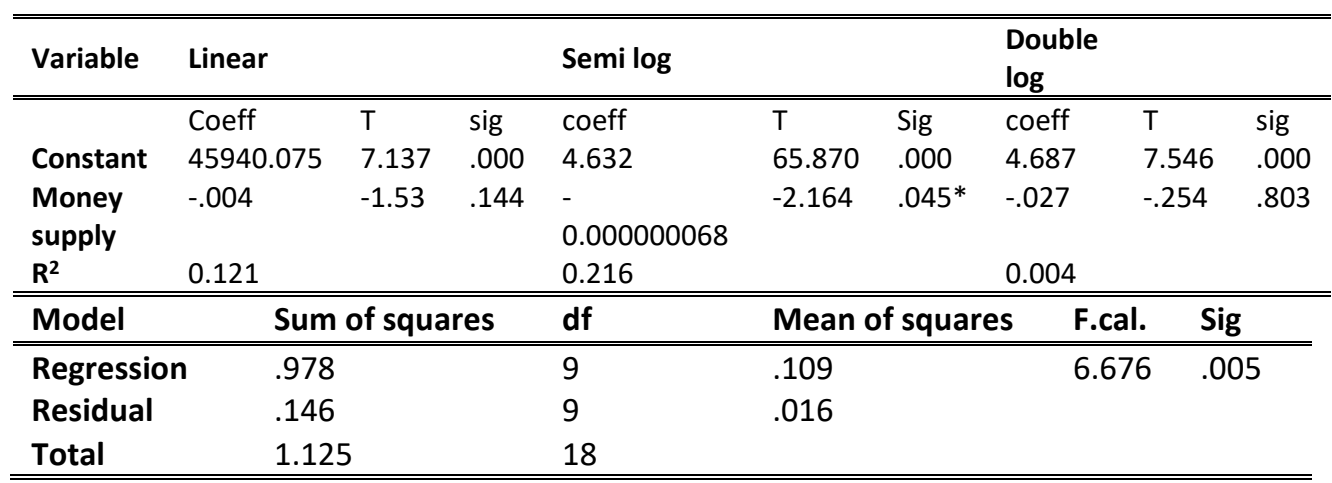

Source: CBN data, 2018

a. Dependent Variable: agribusiness financing

b. Predictor: money supply

* Significant at $5 \%$

The semi-log function of the regressions was accepted as the lead model on the basis of the value of R2, F stat, and the evidence of significant of the exogenous variable in the model. An evaluation of the relationship between financial bailout in agribusiness and money supply was based on the R2 value of $22 \%$ and the $F$ ratio of 6.68. this implies that an increase in money supply will result in an increase in the financial bailout of agribusiness firms. Thus, the null hypothesis which states that money has no significant effect on agribusiness financial bailout is rejected.

Table 3 shows that reserve requirement, interest rate, discount rate, and exchange rate have a positive and significant relationship with money supply. The result of the correlation between macro-economic variables and money supply is comprehensively explained below:

Reserve requirement: The result shows that the reserve requirement is significant at 0.015 . This implies that the amount of capital injected into the agribusiness sector as bailout funds increase as the fund in the central bank reserve increases. The government instructs the central bank to release funds for the bailout of agribusiness firms, in other to prevent the firms from going into extinction in as much as the central bank has enough funds in reserve.

Exchange rate: The result shows that the exchange rate is significant at 0.01 . This depicts that as the exchange rate in the amount of naira increase, the amount of funds required for the bailout of agribusiness firms also increase. 
Achoja, F.O. (2020). Relationship Bbetween Money Supply and Financial Bailout of Small Scale Agribusiness Firms in Nigeria, BILTURK, The Journal of Economics and Related Studies, 2(3), 459-470.

Table 3. Relationship between Money Supply and Macroeconomic Variables

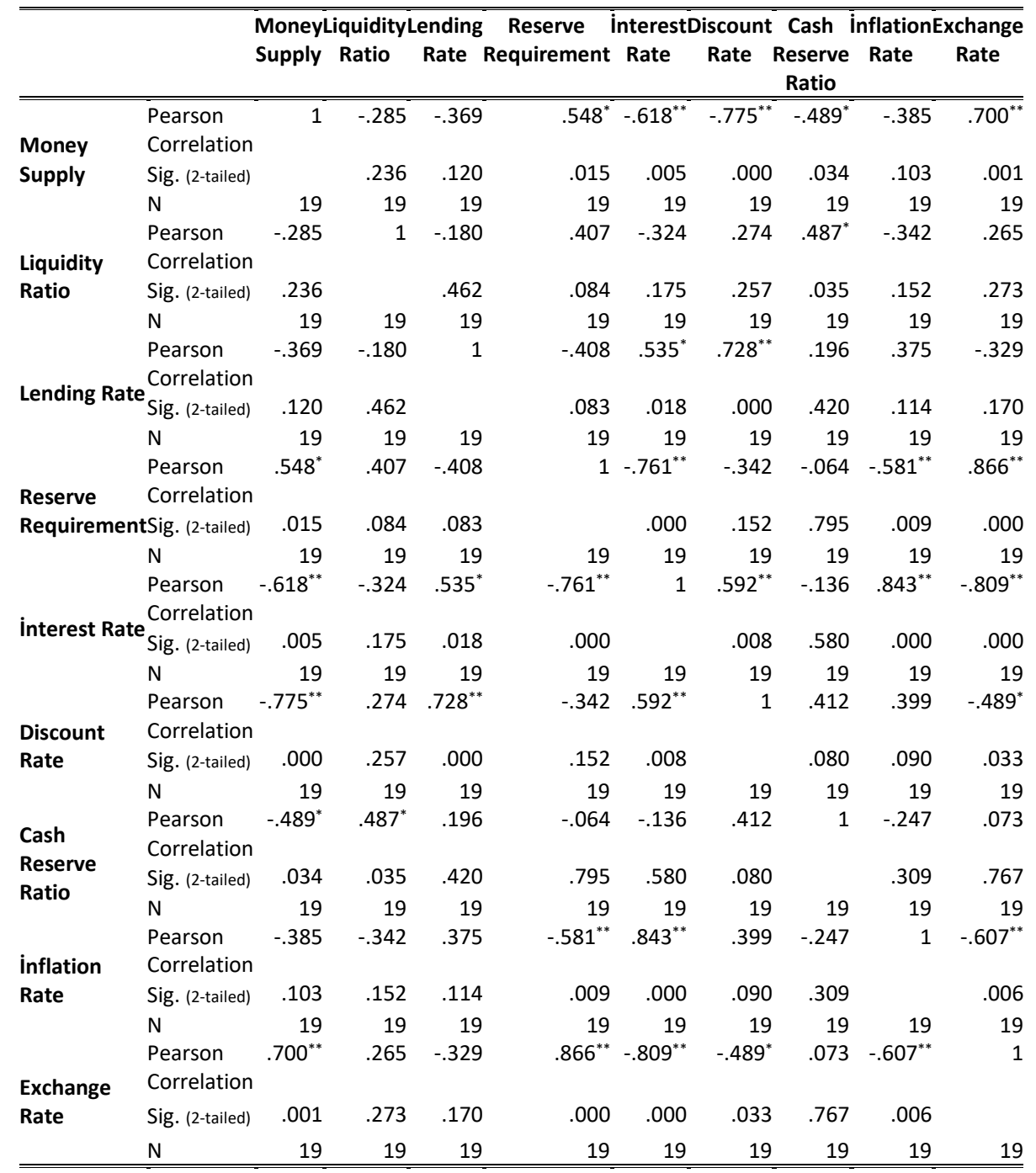

*. Correlation is significant at the 0.05 level (2-tailed).

**. Correlation is significant at the 0.01 level (2-tailed).

The objective of the error correction model is to determine in our case the impact of olive oil exports on long-term economic growth (by testing the significance of Interest rate: The finding shows that interest rate is significant at 0.05 . This finding indicates that if the interest rate charged on borrowed funds is high, farmers will be discouraged from borrowing money from the bank. The bailout funds required will subsequently increase because farmers will prefer to rely on grants from the government. These findings support the earlier report of Central Bank of Nigeria (CBN) (2008) which identified multivariate macroeconomic indicators that have 
effects on agribusiness financing. These include interest rate risk, foreign exchange risk, inflation rate risk, and bank lending rate risk Exchange rates are determined by the forces of demand and supply for currency (World Bank, 2008). To that extent, the exchange rate reveals the purchasing power of the currency (lyoha et al., 2003). An unstable exchange rate usually leads to instability in terms of trade. It creates uncertainties in the domestic economy.

Weaknesses in the financial bailout of small-scale agribusiness firms: Based on a priori expectation the weaknesses in the financial bailout mechanism are a result of financial leakages. When these funds are released to the agribusiness firms they are sometimes diverted to other areas instead of being used for the intended purpose. Even the government agencies in charge of the sector also divert the fund to their personal uses thereby preventing the funds from getting to the actual beneficiaries.

\section{Conclusion}

The empirical results of the investigation lead to the following conclusions. First, the amount of capital injected into the agribusiness firms in the form of bailout is extremely low. Secondly, money supply has a positive and significant relationship with the government financial bailout of agribusiness firms. Thirdly, money supply has a significant relationship with macroeconomic variables. These variables are reserve requirement, exchange rate, and interest rate. Factor analysis revealed that reserved requirement, exchange rate, and interest rate created more significant effect on money supply. Conclusively, in as much as money supply significantly affects the financial bailout of agribusiness firms, reserved requirement, exchange rate and interest rate that have a significant relationship with money supply will accordingly create an important influence on the financial bailout of agribusiness firms. There is a strong link between government financial bailout and macro-economic variables.

Based on the findings of the study, the following recommendations were made: The government should scale up the amount of capital injected into the agribusiness sector to ensure the stability and continuity of production activities in the sector.

Policymakers should base bailout policies on relevant macroeconomic variables (reserved requirement, exchange rate, and interest rate) during economic recession for the purpose of financial intervention in the agribusiness sector.

The government should constitute supervisory agencies that will ensure that bailout funds are not diverted but are used strictly for bailout purposes. 


\section{References}

Adofu, I., Antai E and Alabi, O. (2010), Informal Savings Mobilization and Investment: A Case Study of Rotating Savings and Credit Association (ROSCA) in Kogi State.

Asian Development Bank (2005). Asian development Bank report: www.adb.org/../adb-annual-report/

Ayinde O.E, (2009). Effect of fertilizer policy on crop production in Nigeria Medwell Journals: The social sciences 4(1): pp 53-58

Central Bank of Nigeria (CBN) (2008). Annual Report and Statement of Accounts. Abuja; Central Bank of Nigeria, pp. 107-121.

Cheryl D. B. (1992). overt and covert Bailout "Developing a Public Bailout Policy" Indiana law Journal, Vol. 67 (4) page 951.

Dam, L. and Koetter, M., (2011). "Bank Bailouts, Interventions and Moral Hazard", Banking and Financial Studies, 2(10),1-59.

Deutsche Bundesbank (2007). Financial Stability Report (2007). Frankfurt, Deutsche Bundesbank Diamond, D.W. and Dybvig P. H., (1983), "Bank runs, deposit insurance, and liquidity". Journal of Political Economy, 91, 401-419.

Douglas A, Phillips, (2004). "Nigeria", (Philadelphia: Chelsea House Publisher), p. 10.

Faff, R.., Parwada, J.T. and Tan, K., (2010). "Were Bank Bailouts Effective during the 2007-2009 Financial Crisis? Evidence from Contagion Risk in the Global Hedge Fund Industry", www.bundesbank.de, 1-39.

Iyoha M.A., Oyefusi S.A., Oriakhi D.E. (2003). An Introduction to Modern Macroeconomics. Mindex Publishing Company Ltd, Benin City, pp. 102-105.

Jean, Jacques, D., Alexandra E. (2011). Agriculture and Development: A brief review of literature, World Bank Policy Research Paper No.5553, Development Economics Research Support Unit, January, 2011.

Karlan, Dean and Jonathan Morduch, "Access to Finance," Handbook of Development Economics, Volume 5. Dani Rodrik and Mark Rosenzweig (Eds.), 2009, Chapter 2.

Levitin, A.J., (2011). In Defence of Bailouts", The Georgetown Law Journal, 99,435514. 
Naohisa H. Nao S. and Kozo U. (2013). Capital injection, monetary policy \& financial accelerators in international journal of central banking Vol. 9 (2), page 134.

New York City Seasonal Financing Act of (1975). Pub. L. No. 94-143, § 2, 4(b), 89 Stat. 797.

Oni, S.A. and Olomola, A.S. (1989). Technique of Attracting Credit for Agricultural Development in Africa. Unpublished Paper delivered at the Symposium held in Abuja, Nigeria on Financing and Agricultural Development in Africa, November.

Sanusi, L.S., (2010). The Nigerian Banking Industry: What went wrong and the way forward, CBN Governor's Speech, 1-23.

Townsend, Robert, "Credit Intermediation and Poverty Reduction," in "Abhijit Banerjee, Roland Bénabou and Dilip Mookherjee (eds) Understanding Poverty" Oxford University Press 2006.

World Bank (2008). Yearly Financial Statement of Account. 